http://kitaibelia.unideb.hu/

ISSN 2064-4507 (Online) • ISSN 1219-9672 (Print)

(C) Department of Botany, University of Debrecen, Hungary

26(1): 89-90.; 2021

DOI: $10.17542 /$ kit.26.89

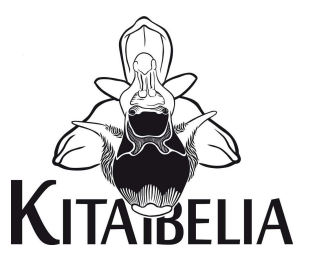

\title{
Szerkesztői közlemény
}

\section{TAKÁCS Attila}

Hat éve jelent meg Magyarország edényes növényfajainak elterjedési atlasza (BARTHA et al. 2015), a hazai flóratérképezési program műhelyének, az - akkor még - Nyugat-magyarországi Egyetem Növénytani és Természetvédelmi Intézetének kiadásában. A botanikus szakma nagy várakozással tekintett elébe az elterjedési térképek publikálásának, hiszen azt megelőzően sok növényfajunk elterjedéséről igen hézagosak voltak az ismereteink. Arra számítottunk, hogy ez a chorológiai atlasz lesz a jövőbeli flórakutatás origója: megbízható és evidens hivatkozási pontja. A kötet megjelenése vitán felül óriási mérföldkő volt a hazai botanikai életben, ám az atlaszt fellapozva - a „Na végre!” és a „Hűha!” lecsengése után - sokunk alapélménye volt a térképek hiányosságainak és hibáinak felismerése. A tipikusabb hibákat, azok forrásait az atlasz szerkesztői később összefoglalták (BARTHA et al. 2019), ami nagyban megkönnyíti az elterjedési adatok helyes és kellően kritikus értelmezését. Ami a hiányosságokat illeti, ezek részben az archív irodalmi és herbáriumi adatok bevallottan csekély feldolgozottságából adódnak. Másrészt pedig nyilvánvalóan mindig lehet egy területen korábban nem észlelt fajokat, újdonságokat találni. A flóraatlasz térképeit böngészve sajnos nem derül ki, hogy az általunk ismert előfordulások helyén az „üres” alapmező adathiány vagy adatfeldolgozás-hiány miatt üres, így az atlasz nehezen felel meg a fent említett tőle elvárt szerepnek. Ezt a szerepet tapasztalataink szerint sokan sokféleképpen látják. Hogy két szélsőséget említsünk: mégis van, aki számára az atlasz az origó, és csak azzal összevetve szeretne florisztikai cikkeket írni, míg mások egyenesen az atlasz teljes negligálását ajánlják.

Mindenesetre sokakban felbuzgott a közlési vágy, a térképek kiegészítésének, javításának az igénye és ezt a törekvést a Kitaibelia megpróbálta becsatornázni. A lapban Pótlások Magyarország edényes növényfajainak elterjedési atlaszához címmel önálló cikksorozat indult az olyan, elsősorban aktuális adatok összegyűjtésére, amiket az adatgyűjtők nem szándékoznak hagyományos florisztikai közleményekben publikálni, de a flóraatlasz térképeihez kiegészítésül szolgálnak. Ezzel kapcsolatban a sorozat első részében így fogalmaztunk: „nem állíthatjuk, hogy minden itt közölt elöfordulás új az adott területre nézve, csupán annyit, hogy BARTHA et al. (2015) térképe kiegészítendö az adattal." (TAKÁcs et al. 2016). A cikksorozat további részeiben többször megismétlődött ez a kijelentés, és általában minden esetben igyekeztünk óvatosan fogalmazni a közölt adatok újdonságát illetően. Értelmezésünkben az itt közölt egyes adatok ekvivalensek a flóratérképezés során keletkezettekkel, és a cikksorozatot nem tekintjük a hagyományos értelemben vett florisztikai munkának, ahol az adatközlés feltétele az irodalmi előzményekkel való összevetés lenne. Ez a megközelítés nem aratott osztatlan sikert, amit néhány informális véleményből kiragadott idézettel illusztrálnánk: „nem túl szerencsés és alapvetően elhibázott lépés a »Pótlások... « cikksorozat.”; „ezek a cikkek így jelen formájukban a botanikai adatközlés »kannásborának« tekinthetők.”; „A fiatalabb generáció ezen sorozaton nevelkedve biztosan nem fog törekedni alapozó flóramüvek fáradságos összeállítására és azt hiszik, hogy ez a florisztika.”; „a »magyar florisztika halála«”. 
A kritikák elsősorban az irodalmazás hiányát fájlalják, ami a sorozat fent vázolt alapkoncepcióját érinti. Egy másik problémakör a cikksorozat adatainak minősége és heterogenitása. Sajnos akadt példa téves adatok közlésére, de ezt nem tartjuk e sorozat sajátságának. Viszont kétségkívül jellemző volt, hogy közönséges fajoktól a kisebb-nagyobb földrajzi léptékben ténylegesen új előfordulási adatokig nagyon színes volt a közölt adatok palettája. Ezzel kapcsolatban a kezdeti álláspontunk az volt, hogy a leggyakoribb fajok kiegészítő adatait publikálás nélkül, közvetlenül az atlasz adatbázisa számára kellene megküldeni, míg a jelentősebb adatokat hagyományos florisztikai cikkben illene bemutatni. Számos alkalommal megtörtént a ritka-gyakori tengely mentén a szélső adatok átirányítása az ezek közlésére alkalmasabb megoldások felé, ahogy irodalmazás nélküli „florisztikai kéziratok” integrálására is volt példa. Sajnos mindebben nem minden szerzővel, szerzőgárdával sikerült békés egyezségre jutni. De a szerkesztők és bírálók láthatatlan munkáját és az erre érkező reflexiókat ne is feszegessük.

A Pótlások Magyarország edényes növényfajainak elterjedési atlaszához c. cikksorozatot a legjobb szándékkal indítottuk el, a fiókban fekvő, szerényebb jelentőségű, önálló közlésre nem ütemezett előfordulási adatok térképre vitelére. Látva, hogy mennyire megosztóvá vált ez a kezdeményezés, a további viták elkerülésére a sorozatot felfüggesztjük. A sorozat 13 részében 65 szerző több mint 12000 adatot közölt, lefedve az ország egész területét. Gyors összevetésül ez az adatmennyiség az atlasz adatbázisának csupán 1\%-át, a 2015 óta bevitt adatoknak viszont 18\%-át jelenti. Ezt számottevő, de nem átütő erejű hozzájárulásként értékeljük, aminek a továbbvitelébe és a vele járó legitimitásvitákba nem kívánunk további energiát ölni.

A flóraatlasz adatbázisának fejlesztése mellett természetesen továbbra is elkötelezettek vagyunk, így arra bíztatjuk minden olvasónkat, hogy a maga eszközeivel segítse ezt a folyamatot (pl. saját publikációk KEF-re kódolt adatainak ill. publikálásra nem szánt adatok beküldése, hibák jelzése az adatbázis adminisztrátorai felé - http://floraatlasz.uni-sopron.hu). Lapunk pedig továbbra is várja a megfelelően kidolgozott botanikai témájú kéziratokat, különösen a florisztikai-növényföldrajzi munkákat.

\section{Irodalom}

Bartha D., Király G., Schmidt D., Tiborcz V., Barina Z., CSIKY J., JAKAB G., LeSKu B., SchmotZer A., VidÉKi R., Vojткó A. \& ZólYomi Sz. (szerk.) (2015): Magyarország edényes növényfajainak elterjedési atlasza. Nyugat-magyarországi Egyetem Kiadó, Sopron, 329 pp.

BARTHA D., SchMidT D. \& TiBoRCZ V. (2019): Magyarország edényes flórájának online elterjedési atlasza (Atlas Florae Hungariae): A honlap felépítése és az adatbázis-építés kilátásai. - Kitaibelia 24(2): 238-252.

Takács A., Nagy T., Sramkó G., Lovas-Kiss Á., Süveges K., Lukács B. A., Fekete R., LöKi V., Malatinszky Á., E. Vojtkó A., Koscsó J., Pfliegler W. P., Nótári K. \& Molnár V. A. (2016): Pótlások a Magyarország edényes növényfajainak elterjedési atlaszához I. - Kitaibelia 21(1): 101-115. 